\title{
PENGARUH PERBEDAAN SIFAT PENYANGGA ALUMINA TERHADAP SIFAT KATALIS HYDROTREATING BERBASIS NIKEL-MOLIBDENUM
}

\author{
Maria Ulfah $^{1 *)}$ dan Subagjo $^{2)}$ \\ ${ }^{1)}$ Jurusan Teknik Kimia-FTI Universitas Bung Hatta-Padang \\ Jl. Gajahmada No. 19, Gunung Pangilun-Padang \\ ${ }^{2)}$ Program Studi Teknik Kimia-FTI Institut Teknologi Bandung \\ Jl. Ganesha 10, Bandung \\ *)Penulis korespondensi: ulfah_nad@yahoo.com
}

\begin{abstract}
EFFECT OF ALUMINA SUPPORT PROPERTIES ON THE NICKEL-MOLIBDENUM BASE HYDROTREATING CATALYST. Effect of surface characteristics of three species of synthesized $\gamma$ alumina (alumina-1, alumina-2 and alumina-3) on characteristics NiMo catalysts has been studied. Those aluminas are derived from boehmite Catapal B by varying rasio mol nitric acid to boehmite. A sol-gel method is used to synthesize $\gamma-\mathrm{Al}_{2} \mathrm{O}_{3}$ support. The Nitrogen adsorption, X-ray diffraction (XRD), Temperature Programmed Reduction (TPR) of $\mathrm{H}_{2}$, Temperature Programmed Desorption (TPD) of $\mathrm{NH}_{3}$, and mechanical strength are used to characterize the supports and catalysts. The results showed that the surface area alumina affects the formation of crystalline $\mathrm{MoO}_{3}$ in the NiMo catalyst, while $\gamma-\mathrm{Al}_{2} \mathrm{O}_{3}-3$ support which has the highest surface area (about $195 \mathrm{~m}^{2} / \mathrm{g}$ ) compared to the other two types of alumina $\left(>195 \mathrm{~m}^{2} / \mathrm{g}\right)$ does not have a crystalline $\mathrm{MoO}_{3}$. The formation of crystalline $\mathrm{MoO}_{3}$ is not influenced by the acidity alumina. Based on the results of XRD, it is indicated that the supported alumina-3 NiMo catalyst (having the highest acid strength) shows that there is no presence of crystalline $\mathrm{MoO}_{3}$. Pore size distribution of support did not change significantly after the deposition of Ni and Mo oxides. Mechanical strength of support also affects the strength NiMo catalyst. Support alumina-3 which has the highest mechanical strength gives the mechanical strength of the highest NiMo catalyst.
\end{abstract}

Keywords: alumina; characteristic of catalyst; characteristic of support; hydrotreating; nickelmolydenum catalyst

\begin{abstract}
Abstrak
Pengaruh sifat penyangga $\gamma$-alumina hasil pengembangan (alumina-1, alumina-2 dan alumina-3) pada karakter katalis hydrotreating nikel-molibdenum (NiMo) telah dipelajari. Ketiga jenis $\gamma$-alumina diturunkan dari boehmite "Catapal B" dengan menvariasikan nisbah mol asam nitrat terhadap boehmite. Pembuatan $\gamma$-alumina menggunakan metoda sol-gel. Adsorpsi Nitrogen, X-ray difraksi (XRD), Temperature Programmed Reduction (TPR) $\mathrm{H}_{2}$, Temperature Programmed Desorption (TPD) $\mathrm{NH}_{3}$, dan kekuatan mekanik digunakan untuk mengkarakterisasi penyangga dan katalis. Hasil penelitian menunjukan bahwa luas permukaan alumina mempengaruhi pembentukan kristalin $\mathrm{MoO}_{3}$ dalam katalis NiMo. Pada penyangga alumina-3 yang memiliki luas permukaan yang paling tinggi ( sekitar $195 \mathrm{~m}^{2} / \mathrm{g}$ ) di banding dua jenis alumina lainnya (>195 $\mathrm{m}^{2} / \mathrm{g}$ ) tidak memiliki kristalin $\mathrm{MoO}_{3}$. Pembentukan kristalin $\mathrm{MoO}_{3}$ tidak dipengaruhi oleh sifat keasaman alumina. Berdasarkan hasil XRD ditunjukan bahwa pada katalis NiMo berpenyangga alumina-3 (memiliki kekuatan asam yang paling tinggi) tidak terdapat adanya kristalin $\mathrm{MoO}_{3}$. Distribusi ukuran pori peyangga tidak berubah signifikan setelah deposisi oksida Ni dan Mo. Kekuatan mekanik penyangga mempengaruhi pula kekuatan katalis NiMo. Penyangga $\gamma \mathrm{Al}_{2} \mathrm{O}_{3}-3$ yang memiliki kekuatan mekanik yang paling tinggi memberikan kekuatan mekanik katalis NiMo yang tertinggi.
\end{abstract}

Kata kunci: alumina; sifat katalis, sifat penyangga; hydrotreating; katalis nikel-molibdenum 


\section{PENDAHULUAN}

Salah satu proses katalitik yang penting di kilang minyak bumi adalah hydrotreating. Hydrotreating merupakan proses hidrogenasi yang berperan untuk menyingkirkan pengotor-pengotor: senyawa sulfur, nitrogen, oksigen, dan logam (terutama $\mathrm{Ni}$ dan $\mathrm{V}$ ) yang terkandung dalam fraksifraksi minyak bumi. Kehadiran kontaminankontaminan ini berakibat pada kerusakan peralatan, katalis, kualitas produk yang rendah dan pencemaran lingkungan (Topsoe dkk., 1996).

Pada industri katalis hydrotreating, $\gamma-\mathrm{Al}_{2} \mathrm{O}_{3}$ merupakan tipe alumina yang sangat menarik karena memiliki luas permukaan yang besar terutama sekitar 250-350 $\mathrm{m}^{2} / \mathrm{g}$ (Satterfield, 1997) dan mampu meregenerasi aktivitas katalitik setelah pemakaian yang intensif pada kondisi operasi yang ekstrim (Satterfield, 1997; Topsoe dkk., 2005; Breyse dkk., 2003). Di samping itu, $\gamma-\mathrm{Al}_{2} \mathrm{O}_{3}$ mudah membentuk nanocluster $\mathrm{MoS}_{2}$ yang stabil (Breyse dkk., 2003). Nanocluster $\mathrm{MoS}_{2}$ yang stabil dapat meningkatkan jumlah dispersi promotor $\mathrm{Ni}(\mathrm{Co})$ pada ujung $\mathrm{MoS}_{2}$, yang mana $\mathrm{Ni}(\mathrm{Co})$ mengakomodasi terbentuknya struktur fasa aktif Ni-Mo-S (Co-Mo-S) (Breyse dkk., 2003; Topsoe dkk., 2005).

Sifat fisika-kimia $\gamma-\mathrm{Al}_{2} \mathrm{O}_{3}$ sangat mempengaruhi unjuk kerja katalis hydrotreating. Okamoto dkk. (1998) menyatakan bahwa luas permukaan alumina merupakan parameter yang sangat menentukan dalam dispersi oksida Mo; dispersi Mo menjadi lebih tinggi bila luas permukaan alumina makin besar. Crespo dkk. (2008) mengamati bahwa katalis NiMo dengan ukuran partikel gamma alumina yang kecil menghasilkan dispersi NiMoS yang lebih tinggi. Moyse dkk. dalam (Topsoe dkk., 1996) telah mengembangkan model sederhana yang menunjukkan hubungan antara ukuran pori penyangga optimum terhadap umpan dan kondisi proses. Pada ukuran pori yang lebih kecil, aktivitas akan dibatasi oleh difusi, sedangkan pada ukuran pori yang lebih besar, luas permukaan aktif akan lebih kecil. Rana dkk. (2005) menyimpulkan bahwa katalis CoMo berpenyangga gamma alumina dengan distribusi pori yang dominan berukuran makro (>500 A) menghasilkan reaksi katalitik hidrodematalisasi (HDM) yang tinggi dan reaksi katalitik hidrodesulfurisasi (HDS) yang rendah. Mulut pori katalis yang memiliki pori berukuran makro lebih sedikit tertutupi oleh logam pengotor dibanding berukuran mikro. Alumina dengan distribusi pori dominan berukuran makro relatif memiliki volume pori yang besar (Rana dkk., 2005; Lussier dan Wallace, 2002). Penyangga dengan volume pori yang besar dapat memuat larutan impregnan yang lebih banyak dan jumlah fasa aktif yang didispersi akan lebih banyak pula. Sifat fisik $\gamma-\mathrm{Al}_{2} \mathrm{O}_{3}$ lainnya yang harus diperhatikan adalah kekuatan mekanik. Katalis dengan kekuatan rendah akan menghasilkan serbuk dalam jumlah lebih banyak yang dapat mengakibatkan channeling, pressure drop yang tinggi dan hot spot (Illiuta dkk., 2006; Topsoe dkk., 1996).
Sifat kimia $\gamma-\mathrm{Al}_{2} \mathrm{O}_{3}$ diidentifikasi dengan pusat asam. Tipe pusat asam yang muncul di permukaan $\gamma-\mathrm{Al}_{2} \mathrm{O}_{3}$ dapat berupa pusat asam Lewis $\left(\mathrm{AlO}^{-}\right)$dan atau pusat asam Brönsted (Al-OH) (Gate dkk., 1979). Menurut Valente dkk. (2006), pusat asam (acid site) permukaan $\gamma-\mathrm{Al}_{2} \mathrm{O}_{3}$ sangat mempengaruhi aktivitas dan selektifitas katalis hydrotreating. Kemampuan untuk dapat mengatur keasaman $\gamma-\mathrm{Al}_{2} \mathrm{O}_{3}$ merupakan hal yang sangat penting. Upaya-upaya untuk memodifikasi keasaman permukaan $\gamma-\mathrm{Al}_{2} \mathrm{O}_{3}$ seperti menambahkan boron, flour, asam fosfat, asam sulfat, memadukan dengan oksida lain (misal: silika) dan sebagainya dalam pembuatan $\gamma-\mathrm{Al}_{2} \mathrm{O}_{3}$ telah dilakukan oleh sejumlah para peneliti.

Boehmite merupakan direct parent dari $\gamma-\mathrm{Al}_{2} \mathrm{O}_{3}$, morfologi dan ukuran partikel boehmite mempengaruhi karakter $\gamma-\mathrm{Al}_{2} \mathrm{O}_{3}$ yang dihasilkan. Sifat boehmite dapat berbeda-beda diantaranya disebabkan oleh metoda pembuatan yang dikembangkan. Ada berbagai cara untuk mensintesis boehmite seperti metodal sol gel, presipitasi, hidrolisis alkoksida alumina, dekomposisi termal aluminium sulfat, deposisi uap logam organik dengan $\mathrm{Al}\left(\mathrm{CH}_{3}\right)_{3}$. Di samping metoda pembuatan boehmite, kondisi pembuatan selama tranformasi boehmite menjadi gamma alumina, juga mempengaruhi sifat penyangga alumina yang dihasilkan. Prosedur dan resep pembuatan gamma alumina yang diturunkan dari boehmite dengan merk dagang "Catapal B" yang sesuai untuk penyangga katalis nafta hydrotreating (Ulfah dan Subagjo, 2012) telah diperoleh. Penelitian tersebut mempelajari peubah-peubah yang mempengaruhi sifat alumina. Hasil penelitian menunjukan bahwa sifat gamma alumina dapat diatur melalui rasio mol asam nitrat terhadap catapal B, rasio mol ammonia terhadap boehmite, lama pengeringan, dan temperatur kalsinasi. Berkaitan dengan judul makalah di atas, penelitian bertujuan untuk melihat pengaruh sifat penyangga alumina terhadap karakter katalis NiMo yang dihasilkan.

\section{BAHAN DAN METODE}

\section{Pembuatan Alumina}

Tiga jenis alumina dibuat dengan metoda solgel; boehmite $(\mathrm{AlOOH})$ dicampur dengan air, asam nitrat dan terakhir dengan penambahan amonium hidroksida. Alumina-1, 2, dan 3 dibuat dengan rasio mol $\mathrm{HNO}_{3} / \mathrm{AlOOH}$ berturut-turut adalah sekitar 0,018; 0,022 dan 0,026. Kondisi pengeringan dan kalsinasi ketiga alumina sama. Boehmite exstruded dikeringkan pada temperatur $120^{\circ} \mathrm{C}$ selama 3 jam dan dilanjutkan dengan kalsinasi pada $550^{\circ} \mathrm{C}$ selama 2 jam.

\section{Pembuatan Katalis}

Katalis NiMo dibuat dengan cara mengimpregnasi penyangga $\gamma-\mathrm{Al}_{2} \mathrm{O}_{3}$ dengan larutan bersifat basa dari campuran nikel nitrat (sebagai sumber Ni) dan molibdenum trioksida (sebagai sumber Mo). Hasil impregnasi kemudian dikeringkan pada temperatur $120^{\circ} \mathrm{C}$ selama 3 jam, dan kalsinasi 
pada $450^{\circ} \mathrm{C}$ selama 2 jam. Untuk mendapatkan katalis NiMo dengan komposisi yang diinginkan: Mo sekitar $17 \%$ b dan $\mathrm{Ni}$ sekitar $4 \% \mathrm{~b}$, rangkaian tahap impregnasi, pengeringan dan kalsinasi dilakukan 2 (dua) kali.

\section{Karakteristik}

Luas permukaan BET, volume pori dan distribusi ukuran pori penyangga dan katalis diukur dengan uji adsorpsi nitrogen pada temperatur nitrogen cair menggunakan NOVA 2000 (Quantachrome) setelah sampel dievakuasi pada $250^{\circ} \mathrm{C}$ selama 3 jam ( $<5 \times 10^{-3}$ Torr).

Pola difraksi serbuk sampel diukur dengan XRD 6000 (Shimadzu) menggunakan radiasi $\mathrm{Cu}$ tanpa filter dengan divergence slit $=1$ derajat, scatter slit $=$ 1 derajat dan receiving slit $=0,3 \mathrm{~mm}$. Kecepatan dan rentang pemidahan (scanning rate dan range scanning) berturut-turut adalah 2 derajat/menit dan 1080.

Profil Temperature Programmed Reduction (TPR) katalis ditentukan dengan $\mathrm{H}_{2}(50 \mathrm{ml} / \mathrm{menit})$ pada ChemBet (Quantachrome). Sebelum sampel sebanyak 0,03 g diukur, sampel dialirkan dengan $\mathrm{He}$ (30 ml/menit) pada $250^{\circ} \mathrm{C}$ selama $3 \mathrm{jam}$. Temperatur reduksi dinaikan dengan laju $10^{\circ} \mathrm{C} /$ menit ke temperatur $900^{\circ} \mathrm{C}$. Profil TPR dicatat dengan thermal conductivity detector (TCD).

Profil kekuatan asam penyangga $(0,5 \mathrm{~g})$ ditentukan dengan Temperature Programmed Desorption (TPD) $\mathrm{NH}_{3}$ pada ChemBet (Quantachrome). Sebelum sampel diukur, sampel dialirkan dengan $\mathrm{He}(50 \mathrm{ml} / \mathrm{menit})$ pada $250^{\circ} \mathrm{C}$ selama 3 jam. Adsoprsi $\mathrm{NH}_{3}$ dilakukan selama 30 menit dengan laju alir $30 \mathrm{ml} / m e n i t$ dan berikutnya temperatur diturunkan hingga $80^{\circ} \mathrm{C}$. Temperatur desorpsi dinaikan dari $80^{\circ} \mathrm{C}$ dengan laju $10^{\circ} \mathrm{C} /$ menit ke temperatur $900^{\circ} \mathrm{C}$ dan $\mathrm{NH}_{3}$ desorption dideteksi dengan TCD.

\section{HASIL DAN PEMBAHASAN \\ Sifat Fisika-Kimia $\mathrm{Al}_{2} \mathrm{O}_{3}$}

Dalam penelitian ini, analisa yang digunakan untuk mengkarakterisasi sifat fisika penyangga adalah X-ray diffratogram (XRD), adsorpsi $\mathrm{N}_{2}$, uji kekuatan tekan secara horizontal dan untuk mengkarakterisasi sifat kimia menggunakan Temperature Programmed Desorption-(TPD) $\mathrm{NH}_{3}$.

Difraksi sinar-X (XRD) serbuk merupakan metoda umum digunakan untuk identifikasi bahan. Setiap jenis bahan akan memiliki pola difraksi yang berbeda-beda. Gambar 1 memperlihatkan pola XRD dari ketiga $\mathrm{Al}_{2} \mathrm{O}_{3}$ hasil pengembagan dan $\gamma-\mathrm{Al}_{2} \mathrm{O}_{3}$ komersial. Ketiga $\mathrm{Al}_{2} \mathrm{O}_{3}$ hasil pengembangan merupakan alumina tipe gamma $(\gamma)$, ditunjukkan dengan adanya puncak-puncak yang spesifik hadir untuk tipe $\gamma$ yaitu pada $2 \theta: 37^{\circ}, 46^{\circ}$ dan $67^{\circ}$ (Okamoto dkk., 1998) dan pola difraktogram ketiga $\mathrm{Al}_{2} \mathrm{O}_{3}$ hasil pengembangan sama dengan $\gamma-\mathrm{Al}_{2} \mathrm{O}_{3}$ komersial.
Alumina fasa $\gamma$ memberikan unjuk kerja katalitik yang lebih tinggi dibanding alumina fasa $\pi$ (Crespo, 2007).

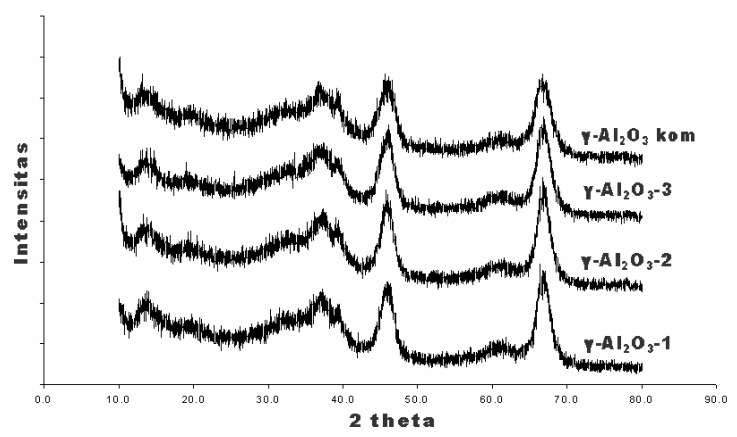

Gambar 1. Pola XRD $\mathrm{Al}_{2} \mathrm{O}_{3}$ hasil pengembangan dan komersial

Adsorpsi Nitrogen merupakan metoda yang digunakan untuk menentukan luas permukaan, diameter pori, dan volume pori bahan. Sifat fisika dari ketiga tipe $\gamma-\mathrm{Al}_{2} \mathrm{O}_{3}$ dan $\gamma-\mathrm{Al}_{2} \mathrm{O}_{3}$ komersial sebagai pembanding diberikan pada Tabel 1 dan Gambar 2.

Tabel 1 Sifat fisika penyangga $\mathrm{Al}_{2} \mathrm{O}_{3}$ hasil

\begin{tabular}{cccc}
\multicolumn{4}{c}{ pengembangan dan komersial } \\
\hline Penyangga & $\begin{array}{c}\text { Luas } \\
\text { permukaan } \\
\left(\mathrm{m}^{2} / \mathrm{g}\right)^{*}\end{array}$ & $\begin{array}{c}\text { Dia. Pori } \\
\text { rata-rata } \\
(\AA)\end{array}$ & $\begin{array}{c}\text { Vol. pori } \\
\text { rata-rata } \\
\left(\mathrm{cm}^{3} / \mathrm{g}\right)\end{array}$ \\
\hline \hline$\gamma-\mathrm{Al}_{2} \mathrm{O}_{3}-1$ & 184,7 & 76,27 & 0,455 \\
$\gamma-\mathrm{Al}_{2} \mathrm{O}_{3}-2$ & 190,0 & 76,60 & 0,462 \\
$\gamma-\mathrm{Al}_{2} \mathrm{O}_{3}-3$ & 195,1 & 76,73 & 0,456 \\
$\gamma-\mathrm{Al}_{2} \mathrm{O}_{3}-$ kom & 220,8 & 76,31 & 0,778
\end{tabular}

*) Diukur dengan Quantachrome Nova 2000

Ket: $\mathrm{NH}_{3} / \mathrm{AlOOH}=0,11(\mathrm{~mol} / \mathrm{mol})$

Temperatur, lama dan laju pengeringan berturutturut: $120^{\circ} \mathrm{C} ; 3$ jam dan $5^{\circ} \mathrm{C} / \mathrm{mnt}$

Temperatur, lama dan laju kalsinasi berturut-turut: $550^{\circ} \mathrm{C}, 2$ jam dan $5^{\circ} \mathrm{C} / \mathrm{mnt}$

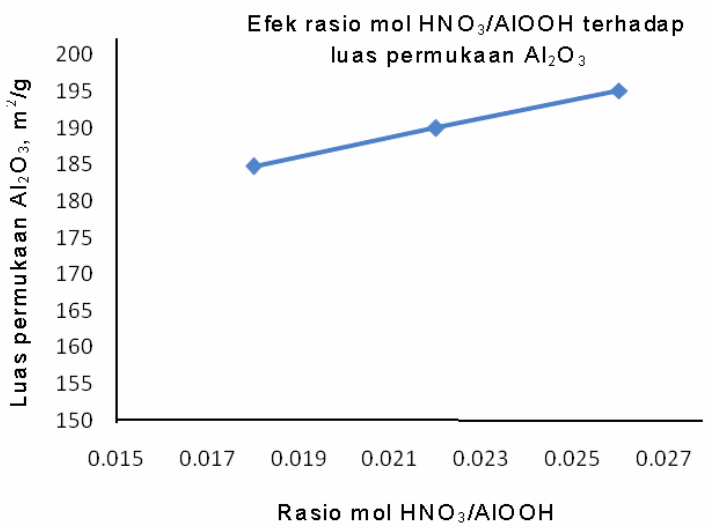

Gambar 2. Efek rasio mol $\mathrm{HNO}_{3} / \mathrm{AlOOH}$ terhadap luas permukaan $\mathrm{Al}_{2} \mathrm{O}_{3}$

Berdasarkan luas permukaan, urutan ketiga penyangga hasil pengembangan sebagai berikut: $\gamma-\mathrm{Al}_{2} \mathrm{O}_{3}-3>\gamma-\mathrm{Al}_{2} \mathrm{O}_{3}-2>\gamma-\mathrm{Al}_{2} \mathrm{O}_{3}-1$. Luas permukaan 
alumina hasil pengembangan tidak sama, jumlah asam nitrat yang ditambahkan berbeda-beda pada masingmasing alumina. Penambahan asam nitrat yang lebih banyak (dalam rentang rasio mol $\mathrm{HNO}_{3} / \mathrm{AlOOH}$ 0,018-0,026) dapat meningkatkan luas permukaan $\gamma-\mathrm{Al}_{2} \mathrm{O}_{3}$ yang dibuat dari catapal B. Penambahan jumlah asam nitrat yang lebih banyak mungkin mengakibatkan jumlah pori-pori berukuran kecil lebih banyak terbentuk dan partikel dengan ukuran pori yang kecil, umumnya memiliki luas permukaan yang besar.

Profil distribusi pori penyangga hasil pengembangan dan komersial disajikan pada Gambar 3. Ketiga $\gamma-\mathrm{Al}_{2} \mathrm{O}_{3}$ hasil pengembangan memperlihatkan distribusi ukuran pori yang sama, dengan ukuran pori dalam rentang 30-150 A. Berdasarkan ukuran pori tersebut, ketiga $\gamma-\mathrm{Al}_{2} \mathrm{O}_{3}$ hasil pengembangan hanya memiliki ukuran pori mesopore (20-500 ̊) (Botchwey, 2010). Penyangga komersial juga hanya memiliki ukuran pori mesopore tetapi dengan distribusi yang lebih lebar 30-250 A. Diameter pori rata-rata penyangga hasil pengembangan dan komersial hampir sama yaitu sekitar $76 \AA$ yang mendekati dengan ukuran molekul fraksi nafta.

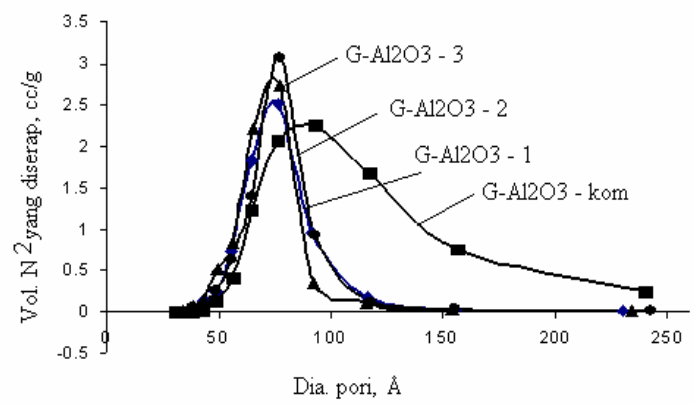

Gambar. 3 Profil distribusi ukuran pori $\gamma-\mathrm{Al}_{2} \mathrm{O}_{3}$ hasil sintesis dan komersial

Sifat kimia penyangga $\gamma-\mathrm{Al}_{2} \mathrm{O}_{3}$ yang berupa tingkat keasaman ditentukan dengan menggunakan TPD- $\mathrm{NH}_{3}$. Profil TPD- $\mathrm{NH}_{3}$ dari $\gamma-\mathrm{Al}_{2} \mathrm{O}_{3}$ hasil pengembangan disajikan pada Gambar 4.

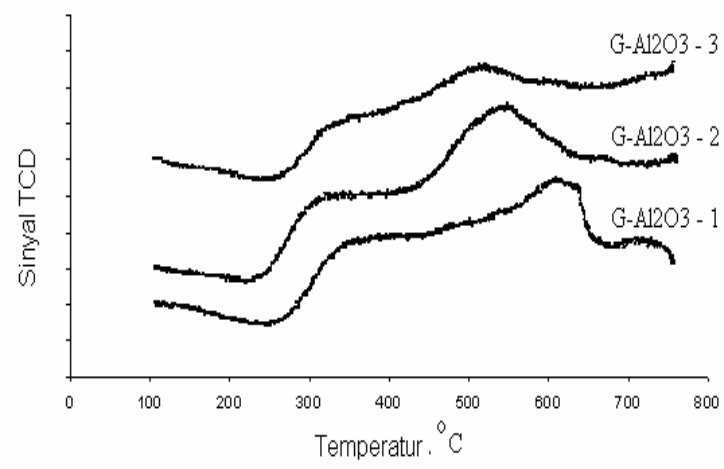

Gambar 4. Profil TPD- $\mathrm{NH}_{3} \gamma-\mathrm{Al}_{2} \mathrm{O}_{3}$ hasil pengembangan
Perbedaan yang utama diantara ketiga alumina tersebut adalah di atas temperatur $600^{\circ} \mathrm{C}$, kurva dari $\gamma-\mathrm{Al}_{2} \mathrm{O}_{3}-1$ dan 2 cenderung turun sedangkan kurva dari $\gamma-\mathrm{Al}_{2} \mathrm{O}_{3}-3$ relatif konstan. Ini menunjukkan bahwa $\gamma-\mathrm{Al}_{2} \mathrm{O}_{3}-3$ memiliki kekuatan asam yang lebih tinggi dibanding $\gamma-\mathrm{Al}_{2} \mathrm{O}_{3}-1$ dan 2 .

Tabel 2 menyajikan kekuatan mekanik dari masing-masing penyangga alumina. Dari tabel tersebut dapat dilihat bahwa semakin tinggi konsentrasi asam nitrat, kekuatan mekanik alumina bertambah. Peningkatan jumlah asam nitrat mungkin menyebabkan ikatan antara partikel-partikel alumina semakin kompak dan akan menambah kekuatan.

Tabel 2. Kekuatan mekanik $\gamma-\mathrm{Al}_{2} \mathrm{O}_{3}$ hasil pengembangan dan komersial

\begin{tabular}{cc}
\hline Penyangga & Crushing strength, $\mathrm{kg} / \mathrm{mm}$ \\
\hline \hline$\gamma-\mathrm{Al}_{2} \mathrm{O}_{3}-1$ & 0,33 \\
$\gamma-\mathrm{Al}_{2} \mathrm{O}_{3}-2$ & 0,45 \\
$\gamma-\mathrm{Al}_{2} \mathrm{O}_{3}-3$ & 0,5 \\
$\gamma-\mathrm{Al}_{2} \mathrm{O}_{3}$-kom & 1,52 \\
\hline
\end{tabular}

\section{Sifat Katalis NiMo dengan Variasi Sifat $\boldsymbol{\gamma}-\mathrm{Al}_{\mathbf{2}} \mathrm{O}_{3}$}

Karakteristik katalis yang diamati dalam penelitian ini adalah identifikasi bahan menggunakan X-ray Diffratogram (XRD); luas permuakaan, diameter pori dan distribusi ukuran pori dengan metoda adsopsi $\mathrm{N}_{2}$; kekuatan katalis secara horizontal, dan identitifikasi tipe molibdem yang hadir menggunakan Temperature Programmed Reduction (TPR) $\mathrm{H}_{2}$

Gambar 5 menyajikan pola XRD dari katalis NiMo dengan variasi sifat $\gamma-\mathrm{Al}_{2} \mathrm{O}_{3}$ hasil pengembangan dan katalis $\mathrm{NiMo} / \gamma-\mathrm{Al}_{2} \mathrm{O}_{3}$ komersial. Selain puncak-puncak untuk $\gamma-\mathrm{Al}_{2} \mathrm{O}_{3}\left(2 \theta: 37^{\circ}, 46^{\circ}\right.$ dan $47^{\circ}$ ), pada katalis $\mathrm{NiMo} / \gamma-\mathrm{Al}_{2} \mathrm{O}_{3}-1$ dan $\mathrm{NiMo} / \gamma-\mathrm{Al}_{2} \mathrm{O}_{3^{-}}$ 2 terdapat puncak kristalin $\mathrm{MoO}_{3} \quad\left(2 \theta: 27,3^{\circ}\right)$ sedangkan pada $\mathrm{NiMo} / \gamma-\mathrm{Al}_{2} \mathrm{O}_{3}-3$ dan $\mathrm{NiMo} / \gamma-\mathrm{Al}_{2} \mathrm{O}_{3}$ ITB-Pertamina, kristalin $\mathrm{MoO}_{3}$ tidak ada. Katalis $\mathrm{NiMo} / \gamma-\mathrm{Al}_{2} \mathrm{O}_{3}$ ITB-Pertamina memiliki luas permukaan penyangga alumina sekitar $195 \mathrm{~m}^{2} / \mathrm{g}$ memuat molibdenum oksida hanya sebesar $10 \%-\mathrm{b}$ dan dengan luas permukaan yang sama, katalis pengembangan memuat oksida komponen aktif sekitar 17\%-b.

Dari Gambar 5 dapat dilihat bahwa intensitas puncak $\mathrm{MoO}_{3}$ pada katalis $\mathrm{NiMo} / \gamma-\mathrm{Al}_{2} \mathrm{O}_{3}-2$ lebih rendah dibanding $\mathrm{NiMo} / \gamma-\mathrm{Al}_{2} \mathrm{O}_{3}-1$. Hal ini karena luas permukaan $\gamma-\mathrm{Al}_{2} \mathrm{O}_{3}-2$ lebih besar daripada $\mathrm{NiMo} /$ $\gamma-\mathrm{Al}_{2} \mathrm{O}_{3}-1$, dapat dilihat pada Tabel 1. Menurut Okamoto dkk. (1998) bahwa luas permukaan penyangga merupakan faktor yang dominan dalam dispersi Mo dan semakin besar luas permukaan penyangga, semakin tinggi dispersi Mo. Dalam katalis hydrotreating, kehadirin kristalin $\mathrm{MoO}_{3}$ tidak diinginkan, karena $\mathrm{MoO}_{3}$ sukar ditransformasi menjadi fasa aktif $\mathrm{MoS}_{2}$. 


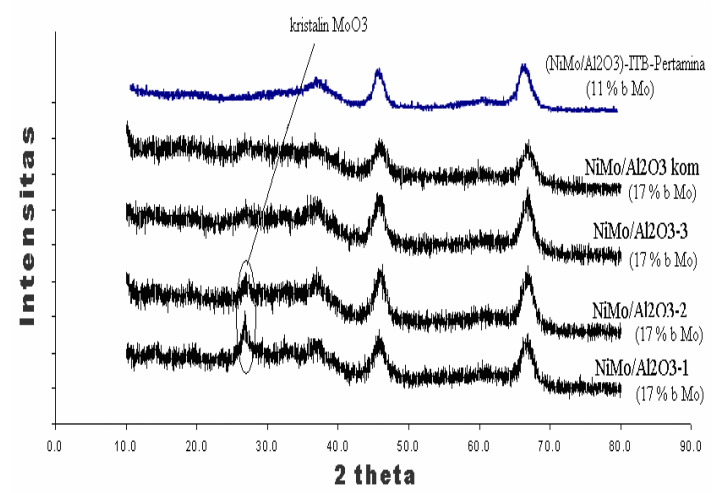

Gambar 5. Pola XRD katalis $\mathrm{NiMo} / \gamma-\mathrm{Al}_{2} \mathrm{O}_{3}$ hasil sintesis dan komersial

Sifat tekstur (luas permukaan, diameter pori dan volume pori) katalis oksida NiMo yang dibuat dengan variasi sifat alumina disajikan dalam Tabel 3. Dari tabel ini dapat dilihat bahwa luas permukaan penyangga alumina berkurang setelah deposisi Mo dan Ni. Pengurangan luas permukaan alumina mencapai 24\%. Pada umumnya, volume dan diameter pori ratarata katalis fasa oksida juga berkurang dibandingkan dengan penyangga. Distribusi ukuran pori baik katalis NiMo hasil pengembangan maupun komersial adalah monomodal diperlihatkan pada Gambar 6. Ketiga $\mathrm{NiMo} / \gamma-\mathrm{Al}_{2} \mathrm{O}_{3}$ hasil pengembangan memiliki distribusi ukuran pori yang sama, dengan ukuran pori dalam rentang 30-150 ̊. Katalis komersial memiliki distribusi yang lebih lebar dengan ukuran pori dalam rentang 30-250 A.

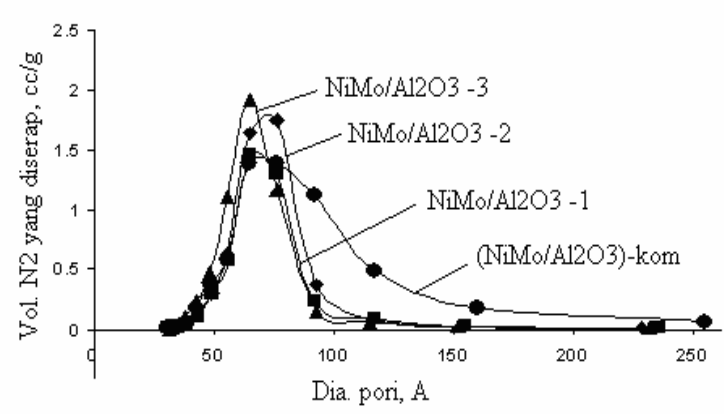

Gambar 6. Profil distribusi ukuran pori katalis NiMo hasil pengembangan dan komersial

Tabel 3. Sifat fisika katalis $\mathrm{NiMo} / \mathrm{Al}_{2} \mathrm{O}_{3}$ hasil sintesis dan komersial

\begin{tabular}{cccc}
\hline Penyangga & $\begin{array}{c}\text { Luas } \\
\text { permukaan } \\
\left(\mathrm{m}^{2} / \mathrm{g}\right)\end{array}$ & $\begin{array}{c}\text { Dia. Pori } \\
\text { rata-rata } \\
(\AA)\end{array}$ & $\begin{array}{c}\text { Vol. } \\
\text { pori } \\
(\mathrm{cc} / \mathrm{g})\end{array}$ \\
\hline \hline $\mathrm{NiMo} / \mathrm{Al}_{2} \mathrm{O}_{3}-1$ & 135,26 & 64,92 & 0,275 \\
$\mathrm{NiMo} / \mathrm{Al}_{2} \mathrm{O}_{3}-2$ & 145,53 & 64,67 & 0,328 \\
$\mathrm{NiMo} / \mathrm{Al}_{2} \mathrm{O}_{3}-3$ & 154,86 & 64,94 & 0,326 \\
$\mathrm{NiMo} / \mathrm{Al}_{2} \mathrm{O}_{3}-$ kom & 188,18 & 64,90 & 0,450 \\
\hline
\end{tabular}

${ }^{\text {*) }}$ Diukur dengan Quantachrome Nova 2000

Ket: Temperatur, lama dan laju pengeringan berturut-turut: $120^{\circ} \mathrm{C} ; 3$ jam dan $5^{\circ} \mathrm{C} / \mathrm{mnt}$

Temperatur, lama dan laju kalsinasi berturut-turut: $450^{\circ} \mathrm{C} ; 2$ jam dan $5^{\circ} \mathrm{C} / \mathrm{mnt}$
Penentukan jenis molibdenum yang hadir dalam katalis dan tingkat kemudahan reduksi Mo menggunakan Temperature Programmed Reduction (TPR) $\mathrm{H}_{2}$. Profil TPR dari katalis oksida NiMo/ $\gamma-\mathrm{Al}_{2} \mathrm{O}_{3}-1, \quad \mathrm{NiMo} / \gamma-\mathrm{Al}_{2} \mathrm{O}_{3}-2, \quad \mathrm{NiMo} / \gamma-\mathrm{Al}_{2} \mathrm{O}_{3}-3$ dan $\mathrm{NiMo} / \gamma-\mathrm{Al}_{2} \mathrm{O}_{3}$ komersial disajikan pada Gambar 7.

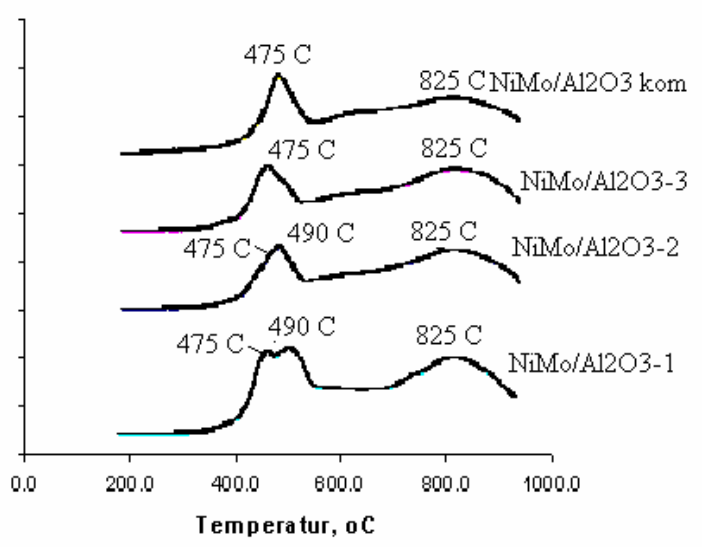

Gambar 7. Profil TPR $\mathrm{H}_{2}$ dari katalis $\mathrm{NiMo} / \gamma-\mathrm{Al}_{2} \mathrm{O}_{3}$ hasil pengembangan dan $\mathrm{NiMo} / \gamma-\mathrm{Al}_{2} \mathrm{O}_{3}$ komersial

Dari gambar tersebut dapat dilihat bahwa ada dua puncak utama yang muncul yaitu pada temperatur 475 dan $825^{\circ} \mathrm{C}$. Kedua puncak ini spesifik untuk katalis NiMo (Crespo dkk., 2008). Puncak pertama $\left(\mathrm{Tm}=475^{\circ} \mathrm{C}\right)$ menyatakan reduksi struktur polimolibdat $\mathrm{Mo}^{+6}$ menjadi $\mathrm{Mo}^{4+}$. Puncak kedua (Tm $=825^{\circ} \mathrm{C}$ ) menyatakan reduksi lanjutan dari puncak pertama dan bersamaan dengan reduksi sebagian $\mathrm{Mo}^{3+}$ menjadi $\mathrm{Mo}^{2+}$. Seluruh sampel memperlihatkan kecendrungan yang sama tetapi dengan intensitas yang berbeda satu sama lainnya. Konsumsi $\mathrm{H}_{2}$ pada kedua puncak untuk katalis $\mathrm{NiMo} / \gamma-\mathrm{Al}_{2} \mathrm{O}_{3}-2$ dan $\mathrm{NiMo} / \gamma$ $\mathrm{Al}_{2} \mathrm{O}_{3}-3$ hampir sama. Untuk katalis komersial, konsumsi $\mathrm{H}_{2}$ pada $\mathrm{Tm}=490^{\circ} \mathrm{C}$ sedikit lebih banyak dari $\mathrm{NiMo} / \gamma-\mathrm{Al}_{2} \mathrm{O}_{3}-2$ dan $\mathrm{NiMo} / \gamma-\mathrm{Al}_{2} \mathrm{O}_{3}-3$, tetapi pada $\mathrm{Tm}=825^{\circ} \mathrm{C}$, konsumsi $\mathrm{H}_{2}$ pada katalis komersial lebih sedikit dari kedua katalis hasil pengembangan. Katalis $\mathrm{NiMo} / \gamma-\mathrm{Al}_{2} \mathrm{O}_{3}-1$ mengkonsumsi hidrogen lebih banyak baik pada $\mathrm{Tm}=475^{\circ} \mathrm{C}$ maupun pada $\mathrm{Tm}$ $=825^{\circ} \mathrm{C}$ dibanding ketiga katalis. Menurut Crespo dkk., (2008), konsumsi hidrogen yang berbeda-beda disebabkan oleh ukuran partikel penyangga alumina, menurut Spojakina dkk. (dalam Crespo dkk., 2008), karena komposisi Mo dipermukaan penyangga yang berbeda-beda. Pendapat lainnya menyatakan reduksi yang kuat terjadi karena interaksi yang kuat antara $\mathrm{Al}_{2} \mathrm{O}_{3}$ dan polimolibdate (dalam Crespo dkk., 2008). Disamping puncak utama, pada profil TPR $\mathrm{H}_{2}$ katalis $\mathrm{NiMo} / \gamma-\mathrm{Al}_{2} \mathrm{O}_{3}-1$ dan $\mathrm{NiMo} / \gamma-\mathrm{Al}_{2} \mathrm{O}_{3}-2$ hasil pengembangan terdapat satu puncak lainnya yaitu pada temperatur $475^{\circ} \mathrm{C}$ yang merupakan puncak kristalin $\mathrm{MoO}_{3}$ (Okamoto dkk., 1998). Kehadiran $\mathrm{MoO}_{3}$ pada katalis $\mathrm{NiMo} / \gamma-\mathrm{Al}_{2} \mathrm{O}_{3}-1$ dan $\mathrm{NiMo} /$ $\gamma-\mathrm{Al}_{2} \mathrm{O}_{3}-2$ juga ditunjukkan pada hasil XRD. 
Tabel 4 menyajikan kekuatan mekanik dari masing-masing katalis NiMo. Setelah deposisi Mo dan $\mathrm{Ni}$, kekuatan mekanik katalis menjadi lebih tinggi dibanding penyangga. Urutan pengurangan kekuatan mekanik katalis NiMo sebagai berikut: $\mathrm{NiMo} / \gamma-\mathrm{Al}_{2} \mathrm{O}_{3}$ $-3>\mathrm{NiMo} / \gamma-\mathrm{Al}_{2} \mathrm{O}_{3}-2>\mathrm{NiMo} / \gamma-\mathrm{Al}_{2} \mathrm{O}_{3}-1$.

Tabel 4. Kekuatan mekanik katalis $\mathrm{NiMo} / \gamma-\mathrm{Al}_{2} \mathrm{O}_{3}$ hasil pengembangan dan komersial

\begin{tabular}{lc}
\hline \multicolumn{1}{c}{ Penyangga } & $\begin{array}{c}\text { Kekuatan mekanik, } \\
\mathrm{kg} / \mathrm{mm}\end{array}$ \\
\hline \hline $\mathrm{NiMo} / \gamma-\mathrm{Al}_{2} \mathrm{O}_{3}-1$ & 0,66 \\
$\mathrm{NiMo} / \gamma-\mathrm{Al}_{2} \mathrm{O}_{3}-2$ & 1,04 \\
$\mathrm{NiMo} / \gamma-\mathrm{Al}_{2} \mathrm{O}_{3}-3$ & 1,08 \\
$\left(\mathrm{NiMo} / \gamma-\mathrm{Al}_{2} \mathrm{O}_{3}\right)-\mathrm{kom}$ & 1,16 \\
\hline
\end{tabular}

\section{Evaluasi Aktivitas Katalis}

Katalis $\mathrm{NiMo} / \gamma-\mathrm{Al}_{2} \mathrm{O}_{3}-1$ memiliki kekuatan mekanik yang rendah (rapuh), sehingga tidak dilakukan uji aktivitas. Gambar berikut ini menyajikan aktivitas katalitik reaksi hidrodesulfurisasi dibenzothiophene (HDS DBT) menggunakan NiMo/ $\gamma-\mathrm{Al}_{2} \mathrm{O}_{3}-2, \mathrm{NiMo} / \gamma-\mathrm{Al}_{2} \mathrm{O}_{3}-3$ dan $\left(\mathrm{NiMo} / \gamma-\mathrm{Al}_{2} \mathrm{O}_{3}\right)$-kom. Aktivitas katalitik $\mathrm{NiMo} / \gamma-\mathrm{Al}_{2} \mathrm{O}_{3}-2$ dan $\mathrm{NiMo} /$ $\gamma-\mathrm{Al}_{2} \mathrm{O}_{3}-3$ relatif sama terhadap reaksi HDS DBT. Hal ini dapat diuraikan dengan penjelasan berikut. Kedua penyangga, $\gamma-\mathrm{Al}_{2} \mathrm{O}_{3}-2$ dan $\gamma-\mathrm{Al}_{2} \mathrm{O}_{3}-3$ memiliki tipe dan jumlah gugus $\mathrm{OH}$ pada permukaan yang hampir sama sehingga tipe molibdenum dan tingkat reduksi molibdenum yang terbentuk pada permukaan $\gamma-\mathrm{Al}_{2} \mathrm{O}_{3^{-}}$ 2 dan $\gamma-\mathrm{Al}_{2} \mathrm{O}_{3}-3$ juga relatif sama (ditunjukkan pada Gambar 7, pola TPR $\mathrm{H}_{2}$ katalis $\mathrm{NiMo} / \gamma-\mathrm{Al}_{2} \mathrm{O}_{3}-2$ dan $\mathrm{NiMo} / \gamma-\mathrm{Al}_{2} \mathrm{O}_{3}-3$ tidak jauh berbeda). Li dkk. (2009) menyebutkan bahwa alumina dengan jumlah gugus $\mathrm{OH}$ yang sedikit dapat menyebabkan interaksi logam Mo-penyangga lemah sehingga, tipe molibdenum yang terbentuk adalah molibdenum polimerik oktahedral yang mudah direduksi.

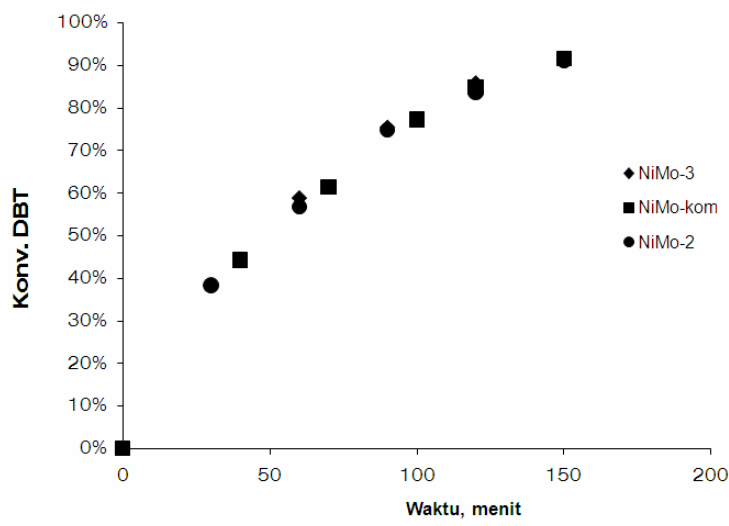

Gambar 8. Aktivitas katalis terhadap reaksi HDS DBT

\section{KESIMPULAN}

Penelitian tentang pengaruh perbedaan sifat penyangga alumina $\left(\mathrm{Al}_{2} \mathrm{O}_{3}\right)$ terhadap sifat katalis hydrotreating berbasis NiMo telah dilakukan. Perbedaan sifat penyangga dilakukan dengan cara memvariasikan rasio mol asam nitrat terhadap boehmite $\left(\mathrm{HNO}_{3} / \mathrm{AlOOH}\right)$. Rasio mol $\mathrm{HNO}_{3} / \mathrm{AlOOH}$ pada $3 \mathrm{Al}_{2} \mathrm{O}_{3}$ yang dikembangkan adalah alumina-1 $\left(\mathrm{Al}_{2} \mathrm{O}_{3}-1\right): 0,018$; alumina-2 $\left(\mathrm{Al}_{2} \mathrm{O}_{3}-2\right): 0,022$ dan alumina-3 $\left(\mathrm{Al}_{2} \mathrm{O}_{3}-3\right)$ : 0,026. Alumina-3 memiliki luas permukaan, kekuatan asam serta kekuatan mekanik yang lebih tinggi dibanding 2 alumina lainnya. Luas permukaan penyangga mempengaruhi karakter katalis hydrotreating NiMo. Katalis NiMo berpenyangga $\mathrm{Al}_{2} \mathrm{O}_{3}-3$ tidak memiliki atau memiliki sekecil mungkin kristalin $\mathrm{MoO}_{3}$ sedangkan, pada NiMo berpenyangga $\mathrm{Al}_{2} \mathrm{O}_{3}-1$ dan $\mathrm{Al}_{2} \mathrm{O}_{3}-2$ terdapat kristalin $\mathrm{MoO}_{3}$.

Kekuatan asam penyangga tidak mempengaruhi pembentukan kristalin $\mathrm{MoO}_{3}$ dalam katalis NiMo. Pada penyangga $\mathrm{Al}_{2} \mathrm{O}_{3}-3$ dengan kekuatan asam yang paling tinggi, ketika diimpregnasi dengan larutan impregnan yang bersifat basa (terdiri dari garam nikel dan oksida molibdenum) tidak terjadi interaksi yang kuat antara alumina dan molibdenum. Distribusi ukuran pori penyangga tidak berubah setelah deposisi fasa aktif; distribusi ukuran pori penyangga dan katalis berada dalam rentang 30-150 Å. Kekuatan mekanik alumina mempengaruhi kekuatan mekanik katalis NiMo. Katalis NiMo dengan penyangga $\mathrm{Al}_{2} \mathrm{O}_{3}-3$ memiliki kekuatan mekanik yang paling tinggi.

\section{UCAPAN TERIMA KASIH}

Penulis mengucapkan terima kasih kepada PT. Pertamina (Persero) yang telah berkenan mendanai penelitian ini melalui pemberian beasiswa S3.

\section{DAFTAR PUSTAKA}

Botchwey, C., (2010), Syntheses, Characterization and Kinetics of Nickel-Tungsten Nitride Catalysts for Hydrotreating of Gas Oil, Disertasi, University of Saskatchewan- Saskatoon.

Breyse, M., Afanasiev, P., Geantet, C., and Vrinat, M., (2003), Overview of Support Effect in Hydrotreating Catalyst, Catalyst Today, 86, pp. 5-16.

Crespo, M.A.D., (2007), Support Effects on Hydrotreating Activity of NiMo Catalysts, Materials Characterization, 58, pp. 864-873.

Crespo, M.A.D., Torres-Huert, A.M., Díaz-Garcíaa, L., Arce-Estrada, E.M., and Ramírez-Meneses, E., (2008), HDS, HDN and HDA Activities of NickelMolybdenum Catalysts Supported on Alumina, Fuel Processing Technology, 89, pp. 788-796.

Gate, B.C., Katzer, J.R., and Schuit, G.C.A., (1979), Chemistry of Catalytic Processes, McGraw Hill, New York.

Illiuta, I., Ring, Z., dan Larachi, F., (2006), Simulating Simultaneous Fines Deposition Under Catalytic Hydrodesulfurization in Hydrotreating Trickle Beds: Does Bed Plugging Affect HDS Performance, Chemical Engineering Science, 61, pp. 1321-1333. 
Lussier, R.J. and Wallace, M.D., (2002), Alumina Trihydarate Derived High Pore Volume, High Surface Area Aluminum Oxide Compiste and Methods of Their Preparation and Use, US patent 640356B1.

Okamoto, Y., Arima, Y., Nakai, K., Umeno, S., Katada, N., Yoshida, H., Tanaka, T., Yamada, M., Akai, Y., Segawa, K., Nishijima, A., Matsumoto, H., Niwa, M., and Uchijima, T., (1998), A Study on The Preparation of Supported Metal Oxide Catalysts Using JRC-Reference Catalysts. I. Preparation of a Molybdena-Alumina Catalyst. Part 1. Surface Area of Alumina, Applied Catalysis A: General, 170, pp. 315328.

Rana, M.S., Ancheyta, J., Maity, S.K., and Rayo, P., (2005), Characteristics of Maya Crude Hydrodemetallization and Hydrodesulfurization Catalysts, Catalysis Today, 104, pp. 86-93.

Richardson (1989), Principle of Catalyst Development, Plenum Press, New York.

Satterfield, C.N., (1991), Heterogeneous Catalysis in Industrial Practice, $2^{\text {nd }}$ Ed. McGraw-Hill, New York.
Topsoe, H., Clausen, B.S., and Masssoth, F.E., (1996), Hydrotreating Catalysis: Science and Technology, Springer, Jerman.

Topsoe, H., Hinnemann, B., Nørskov, J.K., Jeppe V. Lauritsen, J.V., Besenbacher, F., Poul L. Hansen, P.L., Hytoft, G., Egeberg, R.G., and Knudsen, K.G., (2005), The Role of Patways and Support Interactions in the Development of High Activity Hydrotreating Catalyst, Catalyst Today, 107-108, pp. 12-22.

Ulfah, M., dan Subagjo (2012), Hidrodesulfurisasi Dibenzothiophene (HDS DBT) dengan Katalis $\mathrm{NiMo} / \gamma-\mathrm{Al}_{2} \mathrm{O}_{3}$ : Sintesa Penyangga Alumina, Seminar Nasional Teknik Kimia Teknologi Oleo dan Petrokimia Indonesia (SNTK TOPI): Pengembangan Green Technology dan Green Energy untuk Mewujudkan Kemandirian Bangsa, Jurusan Teknik Kimia, Universitas Riau, Pekanbaru.

Valente, J.S, Falcon, S., Lima, E., and Vera, M.A., (2006), Phosphating Alumina: A Tailor Its Surface Properties, Microporous and Mesoporous Materials, 94, pp. 277-282. 